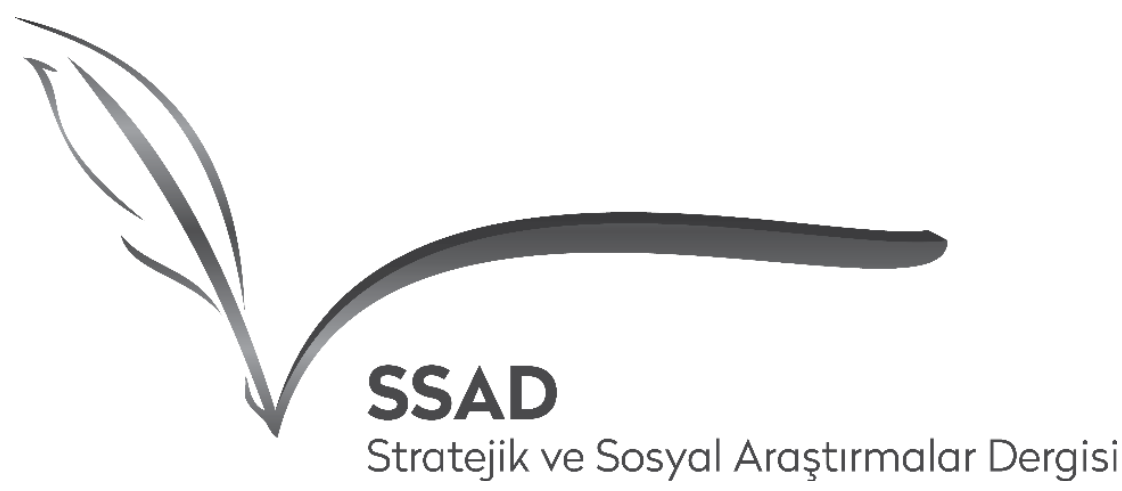

ISSN: $2587-2621$

Volume 2 Issue 3, November 2018

\title{
REPRESENTATION OF POOR PEOPLE IN TELEVISION SERIES: LOST LIFES IN EXTREME REPRESENTATIONS
}

\author{
Televizyon Dizilerinde Yoksul İnsanların Temsili: Aşırı Temsillerdeki Kayıp \\ Yaşamlar
}

\author{
R. Özgün Kehya* \\ Cihan Serdaroğlu**
}

\begin{abstract}
This article analyzes the representation of poor people through the main characters in globally popular American television series. The study employs a systematic content analysis to identify and analyze the main characters that are representing poor people in the four series; Friends, The O.C., 2 Broke Girls and Shameless. The reason for selecting these American series is their popularity and high global rating. Before starting to analyze the series, the literature overview was given to have a realistic perspective about the relationship between popular culture and series, extremity, and statistics about poor people. Moreover, the latest popular series and poor people's representation through the main characters of these series are studied. The series are analyzed under five categories to see how poor people are imaged. According to the hypothesis and the results, when the American series focus on poor characters, they are represented as extreme characters in a negative way generally.
\end{abstract}

Keywords: Poverty, representation, extremity, American TV series, popular culture, crime

Öz: Bu makale, yoksul insanların küresel olarak popüler Amerikan dizilerinde başrol karakterlerle temsil edilmesini analiz etmektedir. Çalışmada, dört dizide yoksul kişileri temsil eden ana karakterleri tanımlamak ve sistematik bir biçimde analiz etmek için içerik analizi kullanılmaktadır. Sözkonusu dizilerin ismi Friends, The O.C., 2 Broke Girls ve Shameless'tir. Bu Amerikan dizileri, popülerliği ve yüksek küresel derecelendirmeleri nedeniyle seçilmiştir. Dizileri analiz etmeye başlamadan önce gerçekçi bir perspektife sahip olmak için popüler kültür ve dizilerin ilişkisi, ekstremite ve araştırmalar ile yoksul insanlara ait istatistiklerle ilgili genel bir bakış sunulmuştur. Aynı zamanda, en son popüler diziler ve bu dizilerin ana karakterleri aracılığıyla yoksul insanların temsili incelenmiştir. Yoksulların nasıl imgelendiğini anlamak için diziler altı kategoride analiz edilmiştir. Hipotez ve sonuçlara göre, Amerikan dizileri yoksul karakterlere odaklandığında genel olarak olumsuz bir şekilde, uçlarda yaşayan karakterler olarak temsil edilmektedirler.

Anahtar Kelimeler: Yoksulluk, temsil, ekstremite, Amerikan televizyon dizileri, popüler kültür, suç

\footnotetext{
*Arş. Gör. Kafkas Üniversitesi, ozgunkehya@gmail.com

** Ankara Üniversitesi, İletişim Fakültesi, Gazetecilik Bölümü Doktora Öğrencisi, cihanserdar@ windowslive.com
} 


\section{Introduction}

Looking at series in America, one can observe two problematical situations about representation of poor people. Firstly, the poor are not represented much. Secondly, when represented, they are presented from a negative perspective, as uneducated, being alcoholic, drug user, and prisoner or in some way being involved in crime and having broken families etc. Such extreme representation of poor people is the fundamental hypothesis in this paper. This kind of representation can cause a wrong impression of poor people and also, it may turn to a real social fact. Therefore, the society could encounter a serious matter. In order to show people such problematical representation, this study is done by a systematic research. The reason for selecting the method of content analysis is that one can have an opportunity to analyze so much content included in this study and thereby gets the opportunity to generalize the results. In the literature, there is not so many research about representation of poor people via main characters. Thus the authors aimed to make up a deficiency in the literature.

In this paper, these four series in America will be analyzed, studying just representation. Therefore the research does not include people's reception on these series. These series are Shameless, 2 Broke Girls, The O.C. and Friends which are chosen, because of the popularity at different times, high rating, having leading roles representing poor people and still continuing. That is important to look at the current circumstance. Four series are enough in terms of scope, because on the The Internet Movie Database (IMDb) charts figured in the "Research Chapter" of this research, there is no other series of which leading roles represent poor people. The reason for choosing American series is that they have high audience ratings worldwide moreover they are in English which makes them international. Besides these, the authors will list the latest and the most popular (top) series according to IMDb ${ }^{1}$, they will not look at all of the number of poor people's representation through the main characters. It is given place to the most popular series, aiming to have and give a general opinion about the rate of poor main characters in the popular series.

In this study, the authors have analyzed four American TV series which are chronologically "Friends", "The O.C.", "Shameless" and "2 Broke Girls". The series have been shot almost different times that Friends from 1994 till 2004, The O.C. from 2003 till 2006, Shameless 2011 till 2016 (Continuing), 2 Broke Girls from 2011 till 2016.

Shameless has been shot for seven seasons and it is still being shot, 2 Broke Girls had been shot for six seasons, The O.C. for four seasons, and Friends, for ten seasons, which is the longest one. While Shameless has twelve episodes for every season and in total, it has eighty four episodes; 2 Broke Girls has twenty four episodes for first three seasons and twenty two episodes for last three seasons and in total, it has one hundred and thirty eight episodes, The O.C. has twenty seven episodes for first season, twenty four episodes for the second season, twenty five episodes of thirty seasons, sixteen episodes for the final season and it has totally ninety two episodes; Friends has twenty four episodes for the first, second, fourth, fifty, seventy, eighty, ninety seasons, twenty five episodes for thirty and sixty seasons, eighteen episodes for the final season and it has totally two hundred thirty six episodes.

\footnotetext{
${ }^{1} \mathrm{http}: / /$ www.imdb.com/ As the website defines itself "IMDb, the world's most popular and authoritative source for movie, TV and celebrity content." According to Alexa traffic ranks, IMDB site has $58^{\text {th }}$ global rank in Monthly Unique Visitor Metrics according to Past 30 Days — Last Updated November 18, 2017. (https://www.alexa.com/siteinfo/imdb.com, Accessed 1809 2017)
} 
Table A.

\begin{tabular}{|l|l|l|l|l|}
\hline & Shameless & $\begin{array}{l}\text { 2 Broke } \\
\text { Girls }\end{array}$ & The O.C & Friends \\
\hline Number of seasons & 7 & 6 & 4 & 10 \\
\hline Total episodes & 84 & 138 & 92 & 236 \\
\hline Continuity & Yes & No & No & No \\
\hline Started & 2011 & 2011 & 2003 & 1994 \\
\hline Finished & 2016 & 2016 & 2006 & 2004 \\
\hline
\end{tabular}

The authors watched all the episodes of the four series and examined them under five categories as asking:

"Are the poor main characters involved in any kind of crime?",

"Do the poor main characters use drugs?",

"Do the poor main characters drink too much?",

"Do the poor main characters have higher educational attainment (at least a college degree)?",

"Do the poor main characters have a broken family?"

And answers as "yes" or "no" were made for these categories. (Please see the "Extreme Representation in American Television Series" and "Poverty and Extremity Relationship: A Literature Overview" chapters to understand how extreme conditions and poverty are linked each other to categorize.) 


\section{Popular Culture and Television Series}

Television series are commercial popular culture products. This research examines the four globally popular series. According to the hypothesis, the poor people aren't represented adequately or if represented in some American series with high ratings, they have extreme behaviors such as alcoholism or drug addiction as a result of poverty. They are represented as uneducated people with broken families. If popular culture reflects society, why is there an image like most of the poor people is scamp and has bad habits?

Even though there are ambiguities in the definition of what popular culture is, it can be basically defined as the culture consumed by majority of people. Ashley Crossman defines the popular culture as accumulation of cultural products that are mostly consumed by working, "uneducated" lower classes of the society opposed to the higher culture of the "educated" elite class. ${ }^{2}$ Popular culture could be considered as and merge with mass culture or global culture, opposite to high culture. Storey has 6 definitions of popular culture and one is related to mass culture. He affirms that popular culture is hopelessly commercial, mass produced for mass consumption. ${ }^{3}$

Popular culture products include music, magazines, film, literature, art, theatre, fashion, dance, painting, internet media and platforms, television and radio programs. It has a commercial aspect; these cultural products are produced by the culture industries to be sold to the masses. By the midnineteenth century, stem-press technologies and railway technologies let the culture of seriality in England, America and the Continent. ${ }^{4}$ Following the mass media innovations in the mid-20th century, after the end of World War 2, popular culture rises and is the entirety of the attitudes, perspectives and ideas within the mainstream of the culture. ${ }^{5}$ The United States of America, by 1949 starts to watch television and 1950's are called the golden age because half of the Americans has televisions in their homes, in other words TV becomes very popular in America. In those years situation comedies, variety shows, and dramas were borrowed from radio adding visual effect to the sound. ${ }^{6}$ Popular American series aren't only watched in America, thanks to satellite, internet technologies and the global broadcasting companies like CNBC'E or E2 channels, it is possible to watch tens of popular American series with subtitles or dubbing.

Popular culture is very important to study because it both shapes the society and reflects the society. For example, in this study the poverty in the series is the reflection of the society and shapes the perceptions of the society. However there could be wrong representation of the poor people and this could serve the popular culture, showing more extreme people in order to be watched more and more. Concerning high ratings and advertisement incomes may push the producers to represent poor people wrongly. Moreover Storey's Gramscian definition considers the popular culture as the tool of elites to keep the masses under control via mass media. ${ }^{7}$ In this approach, the producers of the series that the authors examined are very significant to understand the reason for such representation of poor people. Because the Gramsci's definition has second approach "the popular culture is rebellion against the dominant culture."(Ibid) The ownership of the production companies and the television companies are run by giant media groups. So it is more agreeable to the first approach of the popular culture as a weapon of the dominant elites to

\footnotetext{
2 Ashley Crossman, 2017. [Online]

Available at: https://www.thoughtco.com/popular-culture-definition-3026453

[Accessed 1610 2017].

${ }^{3}$ Storey, J., 2009. Cultural Theory and Popular Culture An Introduction. 5 dü. s.l.:Pearson Education.

${ }^{4}$ Turner, M. W., 2014. Serieization in Popular Culture. Newyork: Routledge.

${ }^{5}$ Reviews, C., 2017. Human Geography, Places and Regions in Global Context. s.1.:Cram 101.

${ }^{6}$ Allen, S. \& Thompson, R. J., 2009. Television in the United States / Brittanica.com. [Online]

Available at: https://www.britannica.com/art/television-in-the-United-States

[Accessed 2709 2017].

${ }^{7}$ Storey, J., 2009. Cultural Theory and Popular Culture An Introduction. 5 dü. s.1.:Pearson Education.
} 
keep the masses under control. The mainstream mass media influences daily lives of the society. In this term the scholar Kongar also claims the power of popular culture: ${ }^{8}$

\footnotetext{
"Consumers, especially young people, who are in the cradle of popular culture develop attitudes and behaviors through fashion patterns and slogans circulating around, without any research or even trouble to think and make decisions: They adopt repetitive marketing slogans, value judgments of the rulers, think, speak and consume according to them."
}

This study is related to the American Popular Culture of which includes globally popular American series having a nomination overseas in foreign film and series sector. According to "the Most Popular TV Shows" of IMDB Charts top 100 ratings and IMDB Ratings, most of them are American series. The IMDB claims that the most popular charts use data from the search of it's more than 250 million monthly visitors to rank the movies and TV shows. ${ }^{9}$

The main features of the Popular Culture regarding series can be summarized as:

- Produced and transmitted by cultural industries: The television channels, the production companies, internet video hosting sites,

- Financially driven, being associated with commercial products: The series have advertisements of some products and services, DVDs, t-shirts,

- Quantitative: Deals with numbers, sells, number of audience, ratings and audience share,

- It's everywhere in the lives of people: On magazines, on social media such as YouTube, Instagram and Facebook etc, publicities, celebrities with iconic figures, conversation starters

- Access in national or Global Level: Via TV Channels, satellite or/ Internet.

In this study, the authors claim that the four series, "Shameless", "2 Broke Girls", "The O.C." and "Friends" are popular, mass media products. And these four series represent the poverty in extreme negative way.

\section{Extreme Representation in American Television Series}

A kind of drama, television series abundantly features extreme: unusual, severe and immoderate characters and scenes. Because fictional products of literature or visual arts need complicated matters, opposite; white and black situations and conflicts to feed the curiosity and adrenalin need of the audience. It is mostly seen that the characters representing extreme in poverty such as crime, drinking too much and drug using in these four series. However, such criminals can be rich or medium class members and poor people have good characters when represented.

Extreme means not usual; exceptional, very severe or serious, far from moderate, especially politically. Extreme poverty, extreme right or left party (right wing extremist or left wing extremist), cumulative extremism, violent extremism, religion extremism are some patterns related to the word "extreme."10

\footnotetext{
${ }^{8}$ Kongar, E., n.d. [Online]

Available at: https://www.kongar.org/aydinlanma/2012/1372_Nefret_Soylemi_Etiketlemeyle_Baslar.php_[Accessed 1017 2017]

${ }^{9} \mathrm{IMDb}, 2017$. En popüler yabancı diziler (IMDb'nin Ağustos 2017 verileri) -1 / NTV. [Online]

Available at: (https://www.ntv.com.tr/galeri/sanat/en-populer-yabanci-diziler-imdbnin-agustos-2017verileri,rN_GqZ0BvkOSi7u1ZXFOmw 27.10.2017)

[Accessed 2308 2017].

${ }^{10}$ Oxford, D., n.d. extreme:Definition of extreme in English by Oxford Dictionaries. [Online]

Available at: https://en.oxforddictionaries.com/definition/extreme

[Accessed 2409 2017].
} 
Since ancient times, philosophy and religions have dealt with extremity. The opposite of extreme and a radical behaviors and opinions, virtue shows high moral quality; it is usual and desirable in the moderate. In ancient Greek philosophy, Aristotle defined a virtue or golden mean/middle way as a desirable point between two extremes; excess and deficiency. (Kelly, 2011, p. 187,189) Extremity is not a balanced way of the life even for the best or worst, too much or too little. In terms of religions, also the virtue is opposite of extreme. For example the Bible says "Whoever fears God will avoid all extremes." - Ecclesiastes 7:18. Islam is called the Middle Path, because it emphasizes moderation rather than extreme opposites.- Quran, 5: 6, Quran, 3: 159 Also Buddhism approaches wisdom of the middle way. ${ }^{11}$

Extremist is a person relating to or characterized by immoderate or excessive actions, opinions, etc". ${ }^{12}$ Extremism has psychological and mental aspects. For example, excessive sexual activities, substance misuse, gambling problem, excessive food intake, difficulties with romantic relationships and internet use or too much shopping are among excessive and extreme behaviors. ${ }^{13}$

Extremities in real life or series are mostly not insufferable and unacceptable by majority of the society. However, immoderate actions can be eighter good or bad relating to the identitity of the character and the reason good or evil. For example killing someone in a series can be just or unjust according to the content of a series. Killing a malefactor by innocent and suffered character, the "action of killing" probable cannot be considered bad. ${ }^{14}$ Apart from the authors' opinions, nevertheless violence such as killing someone is mostly involved in extremist behaviors. Stealing, robbing, lying, cheating are other immoral and extremist actions.

In television series, some characters represent extreme and unique people while some represent ordinary and general ones, as each character has a representation value. The representation of the character can be understood through its accent, clothing, accessories, mimics, house or work. For example a homeless beggar can represent extreme poor people while a teacher from middle class can represent ordinary ones. According to Pembecioğlu, films critize the society. While trying to sell, they hope change in society such unemployment, drug, crime and poverty problems, representing extreme people. ${ }^{15}$

Dramas, films and television series have education \& entertainment function. While entertaining, they try to better viewers to be more virtual and have stronger characters. As the authors claim in the book Positive psychology at the movies: Using films to build virtues and character strengths, the television series are some form of medium promoting social change such as family planning, education of young girls and guiding cycle of poverty. ${ }^{16}$ In terms of our topic, "extreme representation" can be used through poverty and unemployment themes in series, taking the education $\&$ entertainment role of the television into consideration. This study cites three role models of Singhal\&Rogers: positive, negative and transitional models. Positive models are beneficial for the viewers, the negative ones have detrimental lifestyles and transitional models transform their lives changing harmful behaviors into benignant ones. The transitional model is the most effective one because viewer admires the struggle of the character with the difficulties, obstacles or maybe the extreme problems and transformation to the better future. (ibid.) As it is understood from such role model approach, negative and transitional models may contain

\footnotetext{
${ }^{11}$ Nagarjuna, 1995. The Fundamental Wisdom of the Middle Way: Nāgārjuna's Mūlamadhyamakakārikā. New York: Oxford University Press.

12 Dictionary, C., n.d. Extremist Definition and Meaning. [Online]

Available at: https://www.collinsdictionary.com/dictionary/english/extremist

[Accessed 201709 2017].

${ }^{13}$ Punzi, E. H., 2016. International Journal of Qualitative Studies in Health and Well-being, 11(1).

${ }^{14}$ Rhonheimer, M., 2011. The Perspective of Morality: Philosophical Foundations of Thomistic Virtue Ethics. Washington, D.C: Catholic University of America Press.

${ }^{15}$ Pembecioğlu, N., 2014. Narratives Through Turkish Perspective - Transmedia Storytelling And Intertextuality Examples In The Postnetwork Era. Cluj-Napoka: Argonaut Publishing House.

${ }^{16}$ Niemiec, R. M. \& Wedding, D., 2013. Positive psychology at the movies: Using films to build virtues and character strengths. Boston: Hogrefe Publishing.
} 
extremity. For example the series called the Wire deals with the extreme problems such as violence, crime and drug use. According to Vint, the series focuses on poverty and racism as they create drug culture, for example. ${ }^{17}$

As a visual art and drama, television series need to have entertaining function and include extreme characters and scenes. In a series, complicated matters and conflicts in immoderate situations are essential to create adrenalin and arouse curiosity. In this study, the authors claim that the four series, "Shameless", "2 Broken Girls", "The O.C." and "Friends", poverty is the reason for extremity.

\section{Poverty and Extremity Relationship: A Literature Overview}

Poverty can be seen as a resource of evil and a bleeding wound of the society that people want to escape from it. The World Bank defines poverty as:

"Poverty is hunger. Poverty is lack of shelter. Poverty is being sick and not being able to see a doctor. Poverty is not having access to school and not knowing how to read. Poverty is not having a job, is fear for the future, living one day at a time." 18

In this chapter, some literatüre studies will be examined to link poverty with some extreme situations in real life such as having broken families, substance abuse and getting involved in crime. Moreover poverty is linked with insufficient education or lack of opportunities in career development or unemployment in some of these studies. As represented in American series, in real life the facts and the data mostly prove the relationship between the above written negative extreme conditions with the poverty as understood from these researches.

According to the United States Census Bureau, the official poverty rate in 2016 was 12.7 percent in America, there were 40.6 million people in poverty. ${ }^{19}$ The rate may not be seen so much but the poverty involves mostly the children. Among all children in the U.S., 43 percent live in lowincome families and 21 percent lives in a poor family. ${ }^{20}$

Poor conditions and economic problems of families may cause divorcement and separations. For example, as the survey shows that economic and behavioral changes divorce rate falls as twoincome family model matures. These surveys and studies show that income is a factor influencing divorces. ${ }^{21}$ Therefore children of broken families may have to live with a single parent. According to the National Center for Children in Poverty (NCPP) facts, 30 percent of all children residing with married parents live in low-income families and only 11 percent of all children residing with married parents live in poor families. 68 percent of all children residing with a single parent live in low-income families. 40 percent of all children residing with a single parent live in poor families. ${ }^{22}$ Having a broken family may not be a problem itself, however it may cause poverty and vice versa the poverty may cause poverty influencing educational outcomes, job expectancy

${ }^{17}$ Vint, S., 2013. The Wire. Detroit: Wayne State University Press.

${ }^{18}$ Brunswick, G. o. N., n.d. What is poverty? -Economic and Social Inclusion Corporation. [Online]

Available at: http://www2.gnb.ca/content/gnb/en/departments/esic/overview/content/what_is_poverty.html

[Accessed 2510 2017].

${ }^{19}$ Semega, J. L., Fontenot, K. R. \& Kollar, M. A., 2017. Income and Poverty in the United States:2016. [Online]

Available at: https://www.census.gov/en.html

[Accessed 2610 2017].

${ }^{20}$ Jiang, Y., Granja, M. R. \& Koball, H., 2015. NCCP-Basic Facts about Low-Income Children. [Online]

Available at: http://www.nccp.org/publications/pub 1170.html

[Accessed 2610 2017].

${ }^{21}$ Milstead, D., 2012. As Two-Income Family Model Matures, Divorce Rate Falls. [Online]

Available at: https://www.cnbc.com/id/46797203

[Accessed 3010 2017].

22 Jiang, Y., Granja, M. R. \& Koball, H., 2015. NCCP-Basic Facts about Low-Income Children. [Online]

Available at: http://www.nccp.org/publications/pub_1170.html

[Accessed 2610 2017]. 
and involving in crime. The Work and Pensions Secretary of United Kingdom, Iain Duncan Smith says that 7 out of 10 offenders come from broken homes and single parent families were more than twice more likely to live in poverty than those living with both parents. ${ }^{23}$

Poverty has also some educational aspects. A family's financial and motivational support is necessary to have a university degree or college diploma in America. Indeed, the facts of the NCCP reveal that 83 percent of children with parents have less than a high school degree live in low-income families. Only 30 percent of children with at least one parent that has some college or additional education in low-income families. ${ }^{24}$ Education level not only influences the financial situation of families, but also the probability of continuity of marriages. For example the United States Department of Labor claims that probability of divorce declines with educational attainment. "The chance of a marriage ending in divorce was lower for people with more education, with over half of marriages of those who did not complete high school having ended in divorce compared with approximately 30 percent of marriages of college graduates." 25

Less educational attainment, low income or broken families are not a big problem but the results and associableness with the violent victimization (rape/sexual assault, robbery or assault) or drug use are the serious outputs of poverty. For example, The United States Bureau of Justice Statistics released the findings from 2008 to 2012 on the relationship between households' poverty level and nonfatal violent victimization, it is clear that poverty has a link with crime. "Persons in poor households at or below had more than double the rate of violent victimization as persons in highincome households. "26

Even though there is a link between poverty and drug use, lack of money is not completely the reason for drug use. Moreover the drug use may not be the reason for poverty. Certainly these two situations have a complex relationship. Drug use and poverty have the similar features such as low-skilled jobs and status, unstable family and relationships, illegality, being expelled from the school, high arrest rates, poor physical and mental health, and high mortality rates. ${ }^{27}$ Both issues may feed each other, poverty can cause mental states leading to use drug which open a road to crime and worse employment conditions. Yim interlinks these two extreme conditions with a diagram showing effects and directions which could lead a huge circular mess. ${ }^{28}$ In terms of poverty and drug abusement relation, there is a range of complex factors, such as characteristics of the agent of the person and of the environment. Alcohol, coping style, availability of substances, family structure and employment opportunities are other factors related to poverty and drug addiction. Not all people in poverty are on drugs. ${ }^{29}$

\footnotetext{
${ }^{23}$ Bloxham, A., 2010. Children from broken homes 'nine times more likely to commit crimes' - Telegraph. [Online] Available at: http://www.telegraph.co.uk/news/politics/8109184/Children-from-broken-homes-nine-times-morelikely-to-commit-crimes.html

[Accessed 3010 2017].

${ }^{24}$ Jiang, Y., Granja, M. R. \& Koball, H., 2015. NCCP-Basic Facts about Low-Income Children. [Online] Available at: http://www.nccp.org/publications/pub_1170.html

[Accessed 2610 2017].

${ }^{25}$ Aughinbaugh, A., Robles, O. \& Sun, H., 2013. Marriage and divorce: patterns by gender, race, and educational attainment, s.1.: U.S. Bureau of Labor Statistics.

${ }^{26}$ Harrell, E. \& Langton, L., 2014. Bureau Justice Statistics(BJS) -Household Poverty And Nonfatal Violent Victimization, 2008-2012, s.1.: U.S. Department of Justice Office of Justice Programs Bureau of Justice Statistics.

${ }^{27}$ Natioanl Council on Drug Abuse, n.d.

${ }^{28}$ Yim, M., 2015. Addiction and Poverty Connected. [Online]

Available at: https://borgenproject.org/addiction-poverty-connected/

[Accessed 2610 2017].

${ }^{29}$ Smyth, N. J. \& Kost, K. A., 1998. Exploring the Nature of the Relationship Between Poverty and Substance Abuse. Journal of Human Behavior in the Social Environment, pp. 78-79.
} 
The previous studies and researches indicate that there is a link between poverty and education attainment, getting involved in a crime and having broken families. However, in terms of correlation between poverty and drug/alcohol addiction there are few studies examining a direct and casual link between two extreme conditions. Rather than the approach that poverty causes substance abusing, some studies show a reverse situation that drug addiction may cause poverty. Nevertheless, several factors arising from poverty such as mental problems, divorcing, not making enough money for living etc. can cause substance use and committing illegal acts such as selling drugs. By all means, all poor people don't use drugs or not alcoholic. Even most of them do not graduate from a college or university and work as coolie with low salary, there are some poor people who achieve to get out of circle of poverty holding a degree and advancing in her/his career.

As poverty and negative extreme conditions are interrelated; however in the series we mostly see negative representations of poor people. Positive models of poor people in real life should be represented in television series as well. For example the rates of poor people holding college degree may not be so much in the series nevertheless there are people with a considerable amount of in low income families having college or additional education.

Statistics is not everything, especially in social sciences, because none of researchers can study on everybody and there are always social factors which are so complex. Off course, today people know so many things about people thanks to social sciences but there is still so much they do not know either, despite to the researches. On the other hand there is not an absolute uncertainty. However, the researches can just give us a general idea about society or human being, yet generalizing may not be right all the time either. Therefore, one should always keep away from certain statements. What the authors are trying to tell, yes there are researches, statistics etc. and surely, they have a point, but nevertheless they cannot say certain thing about poor people and their life. Regarding this, there is no such a thing, poor people have that life, do those things, cannot do those things etc. and the representation is bothering us, is the negative representation of poor people in general and one cannot see a regular life or a success story about them.

Absolutely, in this study, there is no claim that the authors found certain results. One can only have a general idea or claim about the subject with this research. Off course, as every topic has, there are exceptions with this representation situation and it can be seen them too. The authors are against to the general negative representation of poor people in series. This is the basic claim of this research. 
The Research: Poor People On American Series

The Table Shows Popular Series According to IMDB

\begin{tabular}{|c|c|c|c|c|}
\hline \begin{tabular}{|l|} 
Number of \\
Series
\end{tabular} & Serie's Name & $\begin{array}{l}\text { Production } \\
\text { Year }\end{array}$ & \begin{tabular}{|l|lr} 
IMDb Score & $\begin{array}{l}\text { Is } \\
\text { character? }\end{array}$ \\
\end{tabular} & $\begin{array}{lll}\text { a } & \text { Poor } & \text { Main } \\
\end{array}$ \\
\hline 1 & Game of Thrones & 2011 & 9,5 & No \\
\hline 2 & The Defenders & 2017 & 8,1 & No \\
\hline 3 & Ozark & 2017 & 8,6 & No \\
\hline 4 & The Office & 2005 & 8,8 & No \\
\hline 5 & Suits & 2011 & 8,6 & Yes \\
\hline 6 & Atypical & 2017 & 8,5 & No \\
\hline 7 & Ballers & & 7,6 & No \\
\hline 8 & Teen Wolf & 2011 & 7,7 & No \\
\hline 9 & Vikingler & 2013 & 8,7 & Yes \\
\hline 10 & Ray Donovan & 2013 & 8,3 & No \\
\hline 11 & Shameless & 2011 & 8,7 & Yes \\
\hline 12 & The Sinner & 2011 & 7,8 & No \\
\hline 13 & Friends & 1994 & 8,4 & Yes \\
\hline 14 & Breaking Bad & 2008 & 9,5 & Yes \\
\hline 15 & $\begin{array}{l}\text { American Horror } \\
\text { Story }\end{array}$ & 2011 & 8,2 & No \\
\hline 16 & The Flash & 2014 & 8,1 & No \\
\hline 17 & Supernatural & 2005 & 8,6 & No \\
\hline 18 & Arrow & 2012 & 7,8 & No \\
\hline 19 & $\begin{array}{l}\text { Orange Is The New } \\
\text { Black }\end{array}$ & 2013 & 8,2 & No \\
\hline 20 & Gray's Anatomy & 2005 & 7,7 & No \\
\hline 21 & House of Cards & 2013 & 9,0 & No \\
\hline 22 & Animal Kingdom & 2016 & 8,1 & Yes \\
\hline 23 & 13 Reasons Why & 2017 & 8,5 & No \\
\hline 24 & Modern Family & 2009 & 8,5 & No \\
\hline 25 & Twin Peaks & 2017 & 8,7 & No \\
\hline 26 & Westworld & 2016 & 9,0 & No \\
\hline 27 & Prison Break & 2005 & 8,4 & Yes \\
\hline 28 & Lucifer & 2015 & 8,3 & Yes \\
\hline 29 & Criminal Minds & 2005 & 8,1 & No \\
\hline
\end{tabular}




\begin{tabular}{|l|l|l|l|l|}
\hline 30 & Daredevil & 2015 & 8,7 & No \\
\hline 31 & Teen Wolf & 2011 & 7,7 & No \\
\hline 32 & Iron Fist & 2017 & 7,0 & No \\
\hline 33 & $\begin{array}{l}\text { Wet Hot American } 2017 \\
\text { Summer: Ten Years } \\
\text { Later }\end{array}$ & 7,2 & Yes \\
\hline 35 & $\begin{array}{l}\text { The Big Bang } \\
\text { Theory }\end{array}$ & Orphan Black & 2007 & Yes \\
\hline 36 & Power & 8,4 & Yes \\
\hline 37 & The 100 & 2014 & 8,1 & Yes \\
\hline 38 & $\begin{array}{l}\text { The Handmaid's } \\
\text { Tale } 2017\end{array}$ & 8,7 & No \\
\hline 39 & Preacher & 2016 & 8,1 & Yes \\
\hline 40 & Mr. Mercedes & 2017 & 8,4 & No \\
\hline
\end{tabular}




\section{The Table Shows Poor Main Character Percent in Popular Series}

\begin{tabular}{|l|l|l|}
\hline $\begin{array}{l}\text { There Is a Poor Main character in } \\
\text { Serie }\end{array}$ & $\begin{array}{l}\text { There Is No Poor Main character in } \\
\text { Serie }\end{array}$ & Total \\
\hline 14 & 26 & 40 \\
\hline $35 \%$ & $65 \%$ & $100 \%$ \\
\hline
\end{tabular}

Creating the tables, the authors used IMDB's August 2017 report which includes the most popular fifty series and we have used forty of them. ${ }^{30}$ IMDb's August 2017 report was used because it is the newest and IMDb scores are kind of democratic owing to public opinion. The reason for choosing forty of them is that there are few animated series among them. In addition to this, some of the series' scores are sort of low and finally, we had to limit the list because of the limitation of the research. While selecting that forty series, the priority was given to the ones get high IMDb score. Of course, there are not just American series in this report but like mentioned before, the authors did this research just on American series.

The list includes fifty popular series and there are two series that have been analyzed but there are not the others. However, that does not mean those two series which are not in the list, are not popular. They had popularity in their time and still have it but not that much. These two series have high IMDb scores ${ }^{31}$.

According to the tables, poor people are represented $35 \%$ in those popular series, although there is no poor main character $65 \%$. Therefore, as the authors mentioned earlier, one can say that poor people are not represented so much in the series. Besides, some circumstances in series are questionable. For instance in The Handmaid's Tale, there are maid women, but they are forced to do it (Like a slave), the woman who is not actually poor, but is captured prisoner as a made there. However, as answering the question "Is there a poor main character?", it was "yes" for this series.

\section{Example 1: Shameless}

Shameless focuses on a family, which has five children and an alcoholic father who is never around, lives at the south side of the city which is a ghetto. The mother left home when the oldest daughter was nine years old. She takes care of her brothers and sister, leaves high school in second grade and generally works as a waitress. But her situation changes in the seventh season, as she starts to work as a manager in a diner ${ }^{32}$ and sets up her own business. However, in general, the whole family is a mess.

In Shameless series, there are two main characters (the father and his oldest daughter) representing poverty, the questions will be answered, referencing them.

\footnotetext{
${ }^{30}$ IMDB, n.d. [Online]

Available at: http://www.imdb.com/chart/tvmeter?sort=ir,desc\&mode=simple\&page $=1$

[Accessed 2509 2017].

${ }^{31}$ See: http://www.imdb.com/title/tt1845307/ratings?ref_=tt_ov_rt and

http://www.imdb.com/title/tt0362359/ratings?ref_=tt_ov_rt [Accessed 2509 2017].
} 
Table 1.1.:

Do the poor main characters use drugs?

\begin{tabular}{|l|l|l|}
\hline Yes & No & Total \\
\hline 2 & & 2 \\
\hline
\end{tabular}

Table 1.2.:

Do the poor main characters drink too much?

\begin{tabular}{|l|l|l|}
\hline Yes & No & Total \\
\hline 2 & & 2 \\
\hline
\end{tabular}

Table 1.3.:

Do the poor main characters have higher educational attainment (at least a college degree)?

\begin{tabular}{|l|l|l|}
\hline Yes & No & Total \\
\hline & 2 & 2 \\
\hline
\end{tabular}

Table 1.4.:

Do the poor main characters get involved in any kind of crime?

\begin{tabular}{|l|l|l|}
\hline Yes & No & Total \\
\hline 2 & & 2 \\
\hline
\end{tabular}

Table 1.5.:

Do the poor main characters have a broken family?

\begin{tabular}{|l|l|l|}
\hline Yes & No & \\
\hline 2 & & 2 \\
\hline
\end{tabular}

According to the results, in this series, poor main characters are represented as drunk, using drugs, not having more educational attainment, getting involved in crime, having broken families.

\section{Example 2: 2 Broke Girls}

This series focuses on Caroline's and Max's life which goes on as waitresses in a diner in Brooklyn. Caroline got poor after his father's bankruptcy. Before that, she was wealthy and that is why she went to Wharton University. However, Max who has been always poor and never had a chance to study at a college. Max's family is never around and she never knew about her father and her life was definitely such a mess. Unlike Max's life, Caroline had a good life once.

In 2 Broke Girls series, the questions will be answered using them as base. 
Table 2.1.:

Do the poor main characters use drugs?

\begin{tabular}{|l|l|l|}
\hline Yes & No & Total \\
\hline 1 & 1 & 2 \\
\hline
\end{tabular}

Table 2.2.:

Do the poor main characters drink too much?

\begin{tabular}{|l|l|l|}
\hline Yes & No & Total \\
\hline 2 & & 2 \\
\hline
\end{tabular}

Table 2.3.:

Do the poor main characters have higher educational attainment (at least a college degree)?

\begin{tabular}{|l|l|l|}
\hline Yes & No & Total \\
\hline 1 & 1 & 2 \\
\hline
\end{tabular}

Table 2.4.:

Do the poor main characters get involved in any kind of crime?

\begin{tabular}{|l|l|l|}
\hline Yes & No & Total \\
\hline 1 & 1 & 2 \\
\hline
\end{tabular}

Table 2.5.:

Do the poor main characters have a broken family?

\begin{tabular}{|l|l|l|}
\hline Yes & No & total \\
\hline 2 & & 2 \\
\hline
\end{tabular}

The research results of this series show that poor main characters are represented as persons having problem with alcohol, coming from a broken family and Max got involved in crime, using drug and not educated because of her constant poverty and one cannot see all those negativities with Caroline because once she was wealthy.

\section{Example 3: The O.C.}

The O.C. series focuses on a teen boy's life which includes a single poor mom, her "bad" boyfriend and a "criminal" big brother. After he got in jail with his brother, a lawyer provided him get out of jail on parole, than he had to leave home and started to live with the lawyer and his family who are wealthy, adopted him after that, he got involved in crime sometimes but his life has changed in a positive way. That is why he could go to a college and became an architect and at the end of series he could have a good life. This is so meaningful because, when he was with his biologic family he could not have a chance for a 
having a better life standards or good education. Eventually these happen only when he lives with a wealthy family.

In The O.C. series, there are two main characters but one of them is poor (The boy mentioned before.) and the questions will be answered referencing this boy.

Table 3.1.:

Do the poor main characters use drugs?

\begin{tabular}{|l|l|l|}
\hline Yes & No & Total \\
\hline & 1 & 1 \\
\hline
\end{tabular}

Table 3.2.:

Do the poor main characters drink too much?

\begin{tabular}{|l|l|l|}
\hline Yes & No & Total \\
\hline & 1 & 1 \\
\hline
\end{tabular}

Table 3.3.:

Do the poor main characters have higher educational attainment (at least a college degree)?

\begin{tabular}{|l|l|l|}
\hline Yes & No & Total \\
\hline 1 & & 1 \\
\hline
\end{tabular}

Table 3.4.:

Do the poor main characters get involved in any kind of crime?

\begin{tabular}{|l|l|l|}
\hline Yes & No & Total \\
\hline 1 & & 1 \\
\hline
\end{tabular}

Table 3.5.:

Do the poor main characters have a broken family?

\begin{tabular}{|l|l|l|}
\hline Yes & No & total \\
\hline 1 & & 1 \\
\hline
\end{tabular}

The content analysis of this series shows that the poor main character's only problem is that he got involved in crime several times. Besides he is represented as a person coming from a broken family which gets him into trouble. 


\section{Example 4: Friends}

Finally, a legend series, "Friends" which focuses on six fast friends who are young, live in New York City. They have a funny life, are kind of successful all (two of them got success later). But one of them is the poor (Nevertheless this is not the case that poverty a lot/at all.) having no family, low education level, got involved in "crime" when she was child ${ }^{33}$, she works at temporary jobs and plays guitar in a café and is a street performer. The authors will answer the questions referencing her.

Table 4.1.:

Do the poor main characters use drugs?

\begin{tabular}{|l|l|l|}
\hline Yes & No & Total \\
\hline & 1 & 1 \\
\hline
\end{tabular}

Table 4.2.:

Do the poor main characters drink too much?

\begin{tabular}{|l|l|l|}
\hline Yes & No & Total \\
\hline & 1 & 1 \\
\hline
\end{tabular}

Table 4.3.:

Do the poor main characters have higher educational attainment (at least a college degree)?

\begin{tabular}{|l|l|l|}
\hline Yes & No & Total \\
\hline & 1 & 1 \\
\hline
\end{tabular}

Table 4.4.:

Do the poor main characters get involved in any kind of crime?

\begin{tabular}{|l|l|l|}
\hline Yes & No & Total \\
\hline 1 & & 1 \\
\hline
\end{tabular}

Table 4.5.:

Do the poor main characters have a broken family?

\begin{tabular}{|l|l|l|}
\hline Yes & No & total \\
\hline 1 & & $\mathbf{1}$ \\
\hline
\end{tabular}

According to the results of Friends' content analysis, the main poor character is represented as a person who is not having a higher educational attainment, got involved in "crime" in her childhood and comes from a broken family. Actually there was no even a family at all. At the end

\footnotetext{
${ }^{33}$ She mugged a boy. They used "mugged" word. However we do not know how old she was when did that so did she has a criminal responsibility. Therefore we give crime word in quotation.
} 
of the series, she had a good marriage and it was represented like that was the only salvation for her.

Table:B

Total Analysis:

\begin{tabular}{|l|l|l|l|l|l|}
\hline & $\begin{array}{l}\text { Using } \\
\text { Drug }\end{array}$ & $\begin{array}{l}\text { Drinking } \\
\text { too much }\end{array}$ & $\begin{array}{l}\text { Higher } \\
\text { Educational } \\
\text { Attainment }\end{array}$ & $\begin{array}{l}\text { Involving } \\
\text { Crime }\end{array}$ & $\begin{array}{l}\text { Having } \\
\text { Broken } \\
\text { Family }\end{array}$ \\
\hline Shameless & 2 & 2 & 0 & 2 & 2 \\
\hline 2 Broke Girls & 1 & 2 & 1 & 1 & 2 \\
\hline O.C. & 1 & 1 & 1 & 1 & 1 \\
\hline Friends & 1 & 1 & 0 & 1 & 1 \\
\hline & & & & & \\
\hline Number of Yes & 5 & 6 & 2 & 5 & 6 \\
\hline Total & 6 & 6 & 6 & 6 & 6 \\
\hline & & & & & $\mathbf{0 , 8 3}$ \\
\hline Percentage & $\mathbf{0 , 8 3}$ & $\mathbf{1}$ & $\mathbf{0 , 3 3}$ & & 1 \\
\hline
\end{tabular}

- In total, 6 leading roles represent poverty.

- $\quad 83 \%$ of these leading roles use drugs.

- $100 \%$ drink too much alchol.

- $\quad 33 \%$ educated

- $\quad 83 \%$ involved in crime

- $100 \%$ broken family

\section{Conclusion and Discussion}

There was a time Mahatma Gandhi said, "Poverty is the worst form of violence" (Larsen, 2008); nevertheless today poor people are not represented as ordinary characters, because series need higher ratings. Is that the representation of "truth"? What about empathy and sympathy? Definitely, one can neither say that is the whole truth nor that is the way in general about poor people. This can be another study subject in the future.

The authors started this research with the purpose of showing people that extreme negative representation of poor people in American television series which does not give a nice message. This is related to the popular culture, because series are popular culture products which are consumed by people in global dimension.

According to the results of this research, there is a high negative representation of poor people. They are represented as drunk and having broken families 100\% (Parents are never really around, divorced ones, no father, no mother or no both of them. There are left children), addict for a drug and some way getting involved in crime $83 \%$, higher educational attainment $33 \%$. Their life is literally represented as such a mess. Besides all of these, in this research, the authors just looked at main characters in these series but understudies are represented in a negative way as we have mentioned earlier for main characters which one can obviously see that in Shameless and The O.C. 
However, these negative representations all for are not seen in each series. For Shameless them all is seen, in 2 Broke Girls, them all is seen again but not in whole main characters, in The O.C., there are just two negative representations (getting involved in crime and a broken family) with the main character, although we see them too much, , in Friends, no good education, involved in crime and coming from a broken family with main poor character and in the end of the series, there is no success story about the main poor character who just got married and they showed as it is only success for someone like her.

In conclusion, one cannot see poor people/families as main characters while watching series in general, and when they show up, they are seen as extreme characters in a very negative way which is the main problematic and hypothesis of this study. Besides all of these, the authors do not claim that poor people do not have these negative situations and behaviors; surely, some of them do which is steated under the title of "Poverty and Extremity Relationship: A Literature Overview". However, that does not mean that it has to be always that way, and the thing the authors are against is that poor people generally cannot be gotten an ordinary or "normal" representation. In other words one cannot usually watch a success story about them. Moreover the audience needs to watch them because poor people deserve at least that much. Also, this kind of positive representation can be a positive model for some poor people and it can encourage them in making good something with their life. 


\section{References}

Abuse, N. C. o. D., tarih yok Poverty \& Drug Abuse. [Çevrimiçi]

Available at: http://ncda.org.jm/index.php/publications/drug-talk/66-poverty-a-drug-abuse

[Erişildi: 2610 2017].

Allen, S. \& Thompson, R. J., 2009. Television in the United States / Brittanica.com. [Çevrimiçi] Available at: https://www.britannica.com/art/television-in-the-United-States

[Erişildi: 2709 2017].

Anon., tarih yok [Çevrimiçi]

Available at: https://www.nyu.edu/classes/stephens/History\%20of\%20Television\%20page.htm

Anon., tarih yok [Çevrimiçi]

Available at: https://www.wsj.com/articles/SB108258539159789775

Anon., tarih yok [Çevrimiçi]

Available at: https://www.bls.gov/opub/mlr/2013/article/marriage-and-divorce-patterns-bygender-race-and-educational-attainment.htm

Aughinbaugh, A., Robles, O. \& Sun, H., 2013. Marriage and divorce: patterns by gender, race, and educational attainment, basım yeri bilinmiyor: U.S. Bureau of Labor Statistics.

Bloxham, A., 2010. Children from broken homes 'nine times more likely to commit crimes' Telegraph. [Çevrimiçi]

Available at: http://www.telegraph.co.uk/news/politics/8109184/Children-from-broken-homesnine-times-more-likely-to-commit-crimes.html

[Erişildi: 3010 2017].

Brunswick, G. o. N., tarih yok What is poverty? -Economic and Social Inclusion Corporation. [Çevrimiçi]

Available at:

http://www2.gnb.ca/content/gnb/en/departments/esic/overview/content/what_is_poverty.html

[Erişildi: 2510 2017].

Crossman, A., 2017. [Çevrimiçi]

Available at: https://www.thoughtco.com/popular-culture-definition-3026453

[Erişildi: 1610 2017].

Dictionary, C., tarih yok Extremist Definition and Meaning. [Çevrimiçi]

Available at: https://www.collinsdictionary.com/dictionary/english/extremist

[Erişildi: 201709 2017].

Harrell, E. \& Langton, L., 2014. Bureau Justice Statistics(BJS) -Household Poverty And Nonfatal Violent Victimization, 2008-2012, basım yeri bilinmiyor: U.S. Department of Justice Office of Justice Programs Bureau of Justice Statistics.

IMDb, 2017. En popüler yabancı diziler (IMDb'nin Ağustos 2017 verileri) -1 / NTV. [Çevrimiçi] Available at: (https://www.ntv.com.tr/galeri/sanat/en-populer-yabanci-diziler-imdbnin-agustos- 
2017-verileri,rN GqZ0BvkOSi7u1ZXFOmw 27.10.2017)

[Erişildi: 2308 2017].

IMDB, tarih yok [Çevrimiçi]

Available at: http://www.imdb.com/chart/tvmeter?sort=ir,desc\&mode=simple\&page=1

[Erişildi: 2509 2017].

Jiang, Y., Granja, M. R. \& Koball, H., 2015. NCCP-Basic Facts about Low-Income Children. [Çevrimiçi]

Available at: http://www.nccp.org/publications/pub_1170.html

[Erişildi: 2610 2017].

Kelly, E., 2011. The Philosophy of Nicolai Hartmann. \%1 içindeR. Poli \& C. Scognamiglio, düz. The Philosophy of Nicolai Hartmann. Göttingen: De Gruyter.

Kongar, E., tarih yok [Çevrimiçi]

Available at:

https://www.kongar.org/aydinlanma/2012/1372 Nefret Soylemi_Etiketlemeyle Baslar.php

Larsen, D., 2008. Larcen_ViolenceofPoverty. [Çevrimiçi]

Available at:

https://www.cpp.edu/ ahimsacenter/k12/documents/Larsen_ViolenceofPoverty.pdf

[Erişildi: 1017 2017].

Milstead, D., 2012. As Two-Income Family Model Matures, Divorce Rate Falls. [Çevrimiçi] Available at: https://www.cnbc.com/id/46797203

[Erişildi: 3010 2017].

Nagarjuna, 1995. The Fundamental Wisdom of the Middle Way: Nāgārjuna's

Mūlamadhyamakakārikā. New York: Oxford University Press.

Niemiec, R. M. \& Wedding, D., 2013. Positive psychology at the movies: Using films to build virtues and character strengths. Boston: Hogrefe Publishing.

Oxford, D., tarih yok extreme:Definition of extreme in English by Oxford Dictionaries.

[Çevrimiçi]

Available at: https://en.oxforddictionaries.com/definition/extreme

[Erişildi: 2409 2017].

Pembecioğlu, N., 2014. Narratives Through Turkish Perspective - Transmedia Storytelling And Intertextuality Examples In The Postnetwork Era. Cluj-Napoka: Argonaut Publishing House.

Punzi, E. H., 2016. International Journal of Qualitative Studies in Health and Well-being, 11(1).

Reviews, C., 2017. Human Geography, Places and Regions in Global Context. basim yeri bilinmiyor:Cram 101.

Rhonheimer, M., 2011. The Perspective of Morality: Philosophical Foundations of Thomistic Virtue Ethics. Washington, D.C: Catholic University of America Press. 
Semega, J. L., Fontenot, K. R. \& Kollar, M. A., 2017. Income and Poverty in the United States:2016. [Çevrimiçi]

Available at: https://www.census.gov/en.html

[Erişildi: 2610 2017].

Smyth, N. J. \& Kost, K. A., 1998. Exploring the Nature of the Relationship Between Poverty and Substance Abuse. Journal of Human Behavior in the Social Environment, pp. 78-79.

Storey, J., 2009. Cultural Theory and Popular Culture An Introduction. 5 dü. basım yeri bilinmiyor:Pearson Education.

Turner, M. W., 2014. Serialization in Popular Culture. Newyork: Routledge.

Vint, S., 2013. The Wire. Detroit: Wayne State University Press.

Yim, M., 2015. Addiction and Poverty Connected. [Çevrimiçi]

Available at: https://borgenproject.org/addiction-poverty-connected/

[Erişildi: 2610 2017]. 